\title{
Germination of Amoreuxia wrightii species at risk of extinction in Northeastern Mexico
}

\author{
V. Molina-Guerra ${ }^{a, b}$ (D), B. Soto-Mata ${ }^{a, b}$ (D), E. Alanís-Rodríguez ${ }^{a *}$ (D), E. Jurado ${ }^{a}$ (D), \\ G. Cuéllar-Rodríguez ${ }^{a}$ (D), M. Pando-Moreno ${ }^{a}$ (D) and A. Alcalá-Rojas ${ }^{c}$ \\ ${ }^{a}$ Facultad de Ciencias Forestales, Universidad Autónoma de Nuevo León, Carretera Nacional Linares-Cd, Km 145, \\ Victoria, A.P. 41, 67700, Linares, Nuevo León, México

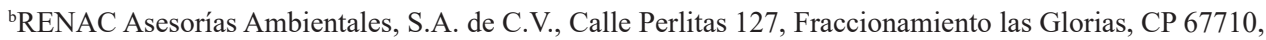 \\ Linares, Nuevo León, México \\ ${ }^{\mathrm{c} C}$ Complejo Siderúrgico TERNIUM, Centro Industrial Ternium, Carretera Pesquería-Los Ramones Km 15, \\ CP 66601, Pesquería, Nuevo León, México \\ *e-mail: eduardo.alanisrd@uanl.edu.mx
}

Received: October 25, 2018 - Accepted: February 18, 2019 - Distributed: May 31, 2020

(With 1 figure)

Bixaceae is a group of perennial plants that includes two genera: Cochlospermum (trees and shrubs) and Amoreuxia (herbaceous); this family has about 15 to 20 species distributed in America, Africa, Asia and Australia (Poppendieck, 1980). In Mexico, Amourexia has four species (A. gonzalezii L. Sprague and Riley, A. malvifolia A. Gray, A. palmatifida DC and $A$. wrightii A. Gray (Rzedowski, 1994).

In the State of Nuevo Leon (northeast of Mexico), there are two species of Amoreuxia: A. palmatifida Moc. \& Sesse ex DC. and A. wrightii A. Gray both listed as endangered in the Mexican Official Standard NOM 059-SEMARNAT- 2010. Amoreuxia wrightii grows mainly in semiarid regions (Cedano, 2000) or in disturbed sites, it is a rare and scarce plant (Rzedowski, 1994) and it is considered as an element of secondary vegetation, usually growing on stony ground (Cedano, 2000).

A. wrightii is herbaceous and perennial with a tuberous root; leaves are long, petioles, and sub-entirely or broadly lobed (5-9); flowers are zygomorphic, yellow to orange with two conspicuous marron marks in the upper petal and one at each lateral petal; the fruit is a subglobose capsule, ovoid or ellipsoidal; seeds are reniform (Rzedowski, 1994) and have a hard, shiny, black outer coat.

It is suspected that $A$. wrightii seeds have physical dormancy caused by water impermeable seeds, as it has been shown that seeds of Bixaceae are water impermeable (Nandi, 1998). To date, no studies have been found regarding seed germination of Amoreuxia wrightii, documenting their dormancy or optimum germination conditions such as temperature and humidity. In here we evaluated, in lab conditions, the speed and the capacity to germinate of $A$. wrightii. Given the hard seed coat present in the seed we hypothezised that seeds must have physical dormancy and tested whether seed scarification promoted germination.

Mature seeds were collected from May to July 2014, in Pesqueria, Nuevo Leon (2544'32" N, 99 57' 45'O, at
$300 \mathrm{~m}$ above sea level). Although some species require a dry after-ripening period to have high rates of germination (Forbis, 2010), we tested fresh seeds as recommended by Baskin et al. (2006). Germination experiments took place right after the seeds were collected. We had two treatments and five replicates. The treatments were: scarified and non-scarified seeds.

The scarification was mechanical with sand paper until part of the seed coat was removed. The non-scarified seeds were used as collected. For the experiment, 20 seeds were placed on filter papers in plastic Petri dishes. The dishes were placed in a bioclimatic chamber (Seedburo Equipment), where moisture was constant $(90 \%)$, temperature was set at $29^{\circ} \mathrm{C}$ during the day and in $22^{\circ} \mathrm{C}$ overnight, with a photoperiod of $12 \mathrm{~h}$ light $/ 12 \mathrm{~h}$ dark. The test ended when there was no more seeds germinating (Baskin and Baskin, 2001); it occurred 39 days after the beginning of the experiment. Germination was considered when a recognizable radicle emerged from the seed coat. Non-germinated seeds period were considered as dormant (Foley, 2001). The " $\mathrm{t}$ " Student test was used to evaluate effects of seed scarification on germination. The statistical program used was SPSS version 22 (SPSS Inc.).

Scarified seeds germinated more $(73 \%)$ than non-scarified ones $(7 \%)(F=3.437$, g.l. $=8, p<0.05)$. Most scarified seeds $(70 \%)$ germinated in the five first days of the experiment, while non-scarified seeds germinated after 30 days of the trail (Figure 1).

Because $>20 \%$ of the seeds germinated after scarification, germinability can be classified as intermediate (Jurado and Westoby, 1992) and because at least 50\% of the seeds germinated between day 1 and 3 the speed is classified as fast. This fast germination of scarified seeds is in contrast to the very slow germination of non-scarified seeds ( $>30 \mathrm{~d}$ ). Perhaps the germination of the latter seeds occurred after damage to the teguments by fungi or other agents as has been found for other arid zone species 


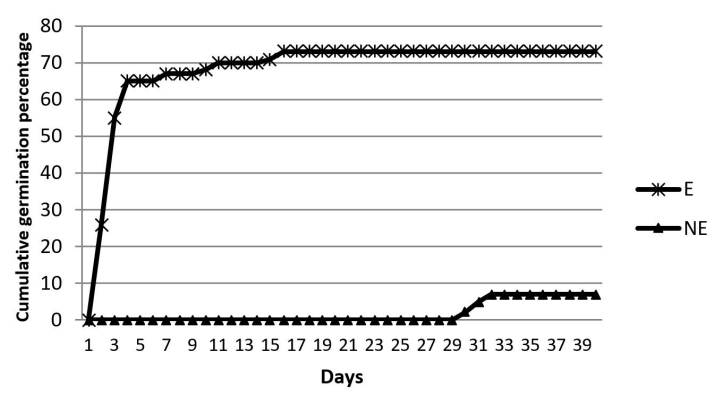

Figure 1. Germination expressed in cumulative percentage of germinated scarified and non-scarified seeds of Amoreuxia wrightii A. Gray (Bixaceae) by the number of days.

(Delgado-Sánchez et al., 2011). Since seed germination of Amoreuxia wrightii was promoted by scarification we support our prediction that the teguments provide physical dormancy. These results may be considered for germination of the species in conservation programs.

\section{REFERENCES}

BASKIN, C.C. and BASKIN, J.M., 2001. Seeds, ecology, biogeography and evolution of dormancy and germination. San Diego: Academic Press, 666 p.

BASKIN, C.C., THOMPSON, K. and M. BASKIN, J., 2006. Mistakes in germination ecology and how to avoid them. Seed Science Research, vol. 16, no. 3, pp. 165-168. http://dx.doi. org/10.1079/SSR2006247.
CEDANO, M., 2000. Revisión de la familia Cochlospermaceae para México. Guadalajara: Universidad de Guadalajara, 241 p. Tesis de Maestría Ciencias Biológicas.

DELGADO-SÁNCHEZ, P., ORTEGA-AMARO, M.A., JIMÉNEZBREMONT, J.F. and FLORES, J., 2011. Are fungi important for breaking seed dormancy in desert species? Experimental evidence in Opuntia streptacantha (Cactaceae). Plant Biology, vol. 13, no. 1, pp. 154-159. http://dx.doi.org/10.1111/j.14388677.2010.00333.x. PMid:21143736.

FOLEY, M.E., 2001. Seed dormancy: an update on terminology, physiological genetics, and quantitative trait loci regulating germinability. Weed Science, vol. 49, no. 3, pp. 305-317. http:// dx.doi.org/10.1614/0043-1745(2001)049[0305:SDAUOT]2.0.CO;2.

FORBIS, T.A., 2010. Germination phenology of some Great Basin native forb species. Plant Species Biology, vol. 25, no. 3, pp. 221-230. http://dx.doi.org/10.1111/j.1442-1984.2010.00289.x.

JURADO, E. and WESTOBY, M., 1992. Germination biology of selected Central Australian plants. Australian Journal of Ecology, vol. 17, no. 3, pp. 341-348. http://dx.doi.org/10.1111/j.1442-9993.1992. tb00816.x.

NANDI, O.I., 1998. Ovule and seed anatomy of Cistaceae and related Malvanae. Plant Systematics and Evolution, vol. 209, no. 3-4, pp. 239-264. http://dx.doi.org/10.1007/BF00985231.

POPPENDIECK, H.H., 1980. A monograph of the Cochlospermaceae. Botanische Jahrbücher für Systematik, Pflanzengeschichte und Pflanzengeographie, vol. 101, no. 21, pp. 191-265.

RZEDOWSKI, G.C., 1994 [viewed 25 October 2018]. Cochlospermaceae. Flora Del Bajio y Regiones Adyacentes [online], vol. 28, pp. 1-6. Available from: https://www.researchgate.net/ publication/288534306_Cochlospermaceae_Flora_del_Bajio_y_ regiones_adyacentes 